\title{
OBITUARY
}

\section{GORDON HANNINGTON LUCE}

Gordon Hannington Luce who died on 3 May 1979 was born on 20 January 1889, the twelfth of thirteen children of the Rev. John James Luce, Vicar of St. Nicholas, Gloucester. His father was a Jerseyman, a member of a longestablished family in that island, and Gordon spent many of his holidays there as a boy. Through his mother he was a cousin of the Oxford historian, Bishop Stubbs. At a very early age he developed a strong taste for literature and history. Indeed, he was something of a child prodigy, reading Homer in Greek at the age of six. Other interests of his were music and gymnastics and it is recorded of him that when one day at table he was reprimanded for being too talkative with the well-known adage ' children should be seen and not heard', he calmly performed a hand-stand on the arms of his chair, held his position and returned to base, amid the silence of the family around the table. He was later to win a half-blue in gymnastics representing Cambridge against Oxford. He was sent to boarding school at the tender age of seven and later went to Dean Close School, Cheltenham, from which he gained a classical scholarship to Emmanuel College, Cambridge.

At Cambridge he read first for the Classical Tripos in which, in 1911, he obtained a first class. He followed this with a further year reading for the English Literature Tripos. During these Cambridge years his extensive circle of friends included many who later achieved distinction. Of these Arthur Waley should be mentioned first since his Cambridge days were exactly contemporaneous with Gordon's; he became a welcome guest of the Waley family during vacations. Mrs. Hubert Waley writes that he became 'the beloved friend of the whole family' and that at Cambridge he was a member of the Apostles. This gave him the entrée to the friendship of such contemporaries as James Elroy Flecker, Rupert Brooke, Aldous Huxley, R. C. Trevelyan, the brother of G. M. Trevelyan, and John Maynard (Lord) Keynes. The last named financed the publication of a volume of Gordon's poems with illustrations by Duncan Grant, also a Cambridge contemporary. His cousin, Professor Rex Warner, tells me; ' His friends at Cambridge included nearly the whole of what is called "the Bloomsbury Set". I remember that I, as a schoolboy, was rather shocked by Gordon's less than enthusiastic response to my question "And did you really know Rupert Brooke?" a poet for whom I felt a youthful adoration. Gordon never spoke unkindly about anyone, but he clearly regarded Brooke's poetry as rather facile and imperfectly thought out. The people of that time whom he chiefly admired and liked were, I think, J. M. Keynes, R. C. (Bob) Trevelyan, E. M. Forster, Virginia Woolf and her sister, Arthur Waley, David Garnett and Duncan Grant. It is a mistake I think to classify him as one of the "Georgian " poets,' he continues, 'he was much better disciplined intellectually than most of them.' Some of these friendships endured for many years, personal contacts being renewed during Gordon's periods of leave from Burma.

In 1912, at the end of his Cambridge days, he sought an overseas post which would give him an opportunity to inspire youth abroad with the humane values of English literature. Thus he came to be appointed Lecturer in English Literature at Government College, Rangoon, a post which carried with it membership of the Indian Educational Service. This institution, which in 1920 was to become a constituent college of the new University of Rangoon, was 
then affiliated to Calcutta University and prepared its students for the Calcutta degree examinations. For part of his journey to Rangoon he sailed with R. C. Trevelyan and E. M. Forster, a journey which the latter was to use as the basis of his book $A$ passage to India.

In Rangoon he developed a lasting friendship with the young Pali scholar Pe Maung Tin, son of U Hpay of Insein, a government servant, at whose house he became a frequent visitor. Pe Maung Tin inspired him with a deep interest in Burmese culture and especially in the art and architecture of Pagan, concerning which the French scholar Charles Duroiselle, the archaeologist employed by the Burma Government, was publishing much authoritative work. His close association with the U Hpay household led to his marriage in 1915 to Ma Tee Tee, the elder of U Hpay's two daughters, thereby forging a link with Burma which became the strongest influence upon the remainder of his long life. Ma Tee Tee was a woman of remarkable charm and high character who herself was destined later to make a contribution of great importance to the life of her country.

Gordon Luce's studies of Burmese culture early resulted in articles contributed to the Journal of the Burma Research Society. The Society had come into existence (in 1910) through the joint efforts of John S. Furnivall of the Indian Civil Service and the Burmese lawyer U May Oung. Gordon's first article entitled ' English poetical translation of the Yadus of Let-we-thon-dara', dealt with the poems of the most famous court poet of the eighteenth century who wrote during the reign of King Hsinbyushin (1763-76), and was contributed to the Journal in 1916. In 1918 he contributed one on 'The greater temples of Pagan'. The antiquities of Pagan were to engage his interest increasingly thereafter: in particular he was attracted by its wealth of inscriptions, already the subject of authoritative studies by C. Duroiselle and C. O. Blagden in Epigraphia Birmanica, the first volume of which was published in 1919. Luce's own earliest contribution to the history of Pagan appeared in the 1919 volume of $J B R S$ and was a review of Charles Duroiselle's The Ari of Burma and Tantric Buddhism.

At the end of World War I the Burma university project, an important item in the Nationalist programme, began to be put into operation by the Burma government, with the result that the new University of Rangoon came into being on 1 December 1920. During the negotiations leading up to this event Gordon Luce was told by Lieutenant-Governor Craddock, the Chancellor of the University, that because of his 'Burmanization' he would not be considered for appointment as its first Professor of English.

Gordon's reaction was to apply for all the leave due to him and to expand his existing Burmese studies at the School of Oriental Studies, which had come into existence in 1917 in London, and at the Sorbonne in Paris. In London he studied Chinese under the direction of Professor Eve Edwards and the languages of the Pagan inscriptions under Dr. C. O. Blagden. In Paris he worked with two well-known sinologists from the Ecole Française d'ExtrêmeOrient of Hanoi, Louis Finot and Paul Pelliot. His study of Chinese was directed towards the exploration of contemporary Chinese writings dealing with their earliest relations with the peoples of Burma. Thus his linguistic studies clearly had a historical objective.

It was during his period of leave that I myself arrived in Burma to take up the headship of the department of History in the University of Rangoon. When the time of his return to Burma was drawing near, I was seeking for ways and means of incorporating Burmese history effectively in the work of 
the History department. This entailed introducing Far Eastern History with special reference to Burma as a new subject. Learning from discussions in the English department that Luce's concentration upon Oriental studies posed problems concerning his teaching there, I advised the creation of a research chair in Far Eastern History, and the offer of the appointment to Luce. I managed to convince both the Government of Burma and the University of Rangoon of the feasibility of the scheme. The University, however, was unwilling to create a research chair. Instead, it offered Luce a readership in history in my department, and he, with his characteristic generosity of spirit, and to my immense gratitude, accepted it. The result was a friendship between us which deepened with the years and extended to the end of his life, though I myself left Burma in 1934 to become headmaster of Caterham School, and did not meet Luce again until his return to England with Daw Tee Tee during World War II, after they had escaped from the Japanese through northern Burma.

In the interval Luce had achieved a great deal. To begin with he had cooperated with Pe Maung Tin in translating three parts of the Hmannan Yazawin (The Glass Palace Chronicle) into English. It was published in 1923. The translation covers parts three, four and five of the chronicle, ending with the fall of Pagan. The wording is entirely that of Gordon Luce. It is in the same sort of archaic English as the Butcher and Lang translation of Homer's Odyssey. The style has been adversely criticized by some of Burma's nationalist writers who failed to realize that it was designed by Luce as a form of tribute to a great work of national literature. His acquaintance with the chronicle, however, brought out the historian's critical faculties in Luce and must have stimulated his desire for evidence as near contemporary as possible, for the chronicle itself was compiled in 1829 and it contained the dynastic myths which had been acceptable to the Konbaung dynasty founded by Alaungpaya in 1752. From these 'fairy stories' he turned to contemporary inscriptions and Chinese dynastic histories for historical facts. For instance, his researches pointed to the earliest Burmese settlements in Burma being made in the ninth century A.D. and to their predecessors, the Tibeto-Burman-speaking Pyu, controlling Upper Burma during the two preceding centuries. This was in complete contrast to the much earlier dates suggested by the Glass Palace Chronicle. His treatment of the Pyu is to be found in two articles in JBRS, the first entitled 'Names of the Pyu', in 1932 and the second, 'The ancient Pyu' in 1937. Luce summarized his views about the early history of Burma for the first time in an article written jointly with Pe Maung Tin entitled 'Burma down to the fall of Pagan : an outline, part 1', published in JBRS, 1939. It was not until a good many years later in 1959 that he gave details regarding the entrance of the Burmese into Burma in the ninth century A.D. in another article in $J B R S$ entitled 'Old Kyaukse and the coming of the Burmans'.

Having joined the History department, Gordon Luce concentrated mainly upon his own research work. On the one hand he was exploring Chinese writings for evidence regarding early Burma and in pursuit of this he published a survey of relevant Chinese writings in $J B R S$ in 1924. He also plunged himself fully into the study of the languages of the earliest inseriptions, Pali, Pyu and the archaic forms of Burmese and Mon. At the same time he began a search for further inscriptions of the Pagan period, training his servant Maung Sein to assist in the work of discovery with highly satisfactory results. In his vacations he made several visits to Pagan itself. He soon became a highly competent 
archaeologist, supplementing the work already done on the site by the Burma Archaeological Department which had come into existence earlier in the century. His archaeological studies, which included making hundreds of rubbings of inscriptions, showed the need for a thorough revision of the transcriptions of inscriptions to be found in Epigraphia Birmanica. The method he adopted for taking rubbings showed up many imperfections in this great work, and he persuaded Rangoon University to sponsor the publication of photogravures of these rubbings as a major step towards making available this immensely rich source of historical and linguistic evidence to other scholars. The first portfolio of these was published in 1933 by Oxford University Press. Eventually, five large portfolios were published during his lifetime, covering the period up to the foundation of the Burmese capital of Ava in 1364-5. At the same time he was making translations and commentaries upon these inscriptions.

All this work was stopped by the Japanese invasion of Burma in 1942, when he and Daw Tee Tee made their way into northern Burma and escaped into India by the perilous mountain tracts through the Naga country. He told me afterwards that Naga bearers carried Tee Tee in an improvised litter, while refusing to accommodate him in similar fashion because of his weight. He therefore had to do the journey on foot. Luckily he was an excellent walker, having already earlier in his career climbed Kanchenjunga with Kingdon Ward. Before leaving Rangoon he deposited his vast collection of transcriptions and notes in the University library for safety. Unfortunately, shortly before the Japanese forces evacuated Rangoon in 1945, they exploded a bomb in the library which did considerable damage to the interior as well as blowing off much of the roof, and before the situation could be retrieved the onset of the monsoon rains destroyed most of the contents of the library including all of Luce's materials. Much of what was lost was irreplaceable.

Gordon Luce himself returned to Burma as soon as possible after the Japanese surrender and applied himself to the immense task of doing again all the work that had been lost. At the same time Daw Tee Tee reopened her 'Home for Waifs and Strays' which had been closed during the Japanese invasion. I should explain here that Gordon and Daw Tee Tee had two children, whom at an early age they had taken to England and settled in a co-educational boarding school at Keswick. Separated thus from her children Tee Tee had started a home for homeless and parentless little boys in a bungalow close to the present university site then in the course of construction. She obtained these by scouring the slums of Rangoon one night. In their new home she cared for them herself and invited student assistance. To finance the scheme she founded a small society of private donors and obtained valuable assistance from the Municipality of Rangoon, which made possible the provision of more extensive buildings permitting a large expansion of its numbers. Gordon actively supported the venture in all sorts of ways and particularly by teaching gymnastics. When I visited the Home in its early days, Tee Tee had twenty-four little boys there, regular little gamins. They sat around on the floor and sang to me, and I thought I had never before seen a group of children so happy. At the close of the Japanese war there were many more homeless children to be collected from the ravaged areas and she was soon receiving numbers of small boys discovered by the Burmese troops in mopping-up operations. By 1952 the Home had become quite a large establishment, all the larger because of the civil war which had raged in Burma since it became independent in January 1948. She and Gordon lived at the Home in their own quarters and 
Gordon himself gave the boys coaching in gymnastics and in eurythmics, using his splendid collection of Western classical music for them to interpret. In 1955 , on a visit to the Home, I watched about a dozen of the boys learning to interpret an orchestral work by Bach with Gordon Luce in command.

The post-war Scarbrough Commission's recommendations envisaged a considerable expansion of South-East Asian studies at the School of Oriental and African Studies in London. This involved inviting Gordon Luce to occupy there a chair in Tibeto-Burman Languages. Owing, however, to his selfimposed post-war commitments in Rangoon, he was unwilling to accept a permanent post in England. In 1949 when I became head of the new department of South-East Asia and the Islands in the School, I managed to persuade him to accept a visiting professorship for one year in 1950 . We were lucky in persuading him to stay until 1953. Early in that year, when I was on study leave in Burma, my colleagues in the University of Rangoon told me that they intended to create a special post for Gordon Luce in the University and 'steal" him from me. I replied that such an effort on their part must succeed since his heart was firmly in Burma, and indeed Daw Tee Tee herself had remained at the Home throughout the period of Gordon's stay in England. The upshot was that he returned to the University of Rangoon to a Chair of History specially created for him, and a new period of intense literary activity began in his life.

Soon after his arrival in England during the war he had been invited to lecture to the India Society in London and chose as his theme "A century of progress in Burmese history and archaeology'. It was not only a most useful survey of the progress made up to the Japanese invasion, but also a sketch of what he considered to be the most necessary next steps in both fields when peace should once more be restored. This lecture forms an indispensable introduction to the work he accomplished during the ensuing years. He was to remain at the University of Rangoon teaching, researching and writing for the next eleven years. During this period he and Tee Tee lived at the Home and with them lived J. S. Furnivall who, at the end of the war, had, like them, returned to Burma to re-open his Burma Book Club. When Independence came to the country in 1948 he was given an advisory post in the new government's planning department.

In $1962 \mathrm{U}$ Nu's government was overthrown by an army coup led by General $\mathrm{Ne} \mathrm{Win}$, and one result of this was a purge of foreigners. Furnivall was the first to be ordered to leave. Then in 1964 came the turn of the Luces. Gordon himself was ordered to leave the country, but Daw Tee Tee was told personally by General Ne Win that he would like her to remain at the Home. Her natural reply was to the effect that her place was with Gordon and accordingly they left the country. Gordon had had his exceptionally fine library packed in about a dozen huge cases. These, however, were impounded by the government of Burma. Indeed, under a regulation that no jewellery could be taken out of the country, Daw Tee Tee was even stripped of her wedding ring when they embarked on the homeward-bound ship, leaving all their possessions behind. Only after representations made by the British Foreign Office to the Government of Burma were the library and other personal possessions of the Luces restored to them. They settled in Jersey, sharing part of a farmhouse belonging to a member of Gordon's family: its coach house was transformed into a very suitable home for the library and in this Gordon worked happily for the next fifteen years. He declined offers of visiting posts made to him by SOAS and some American universities. Actually, these last years in Jersey 
were some of the most fruitful of his career, since to them belongs his crowning achievement, the publication of his monumental Old Burma-Early Pagán (1969-70).

During the post-war years Gordon Luce was the recipient of significant honours. In 1952 he was awarded the C.B.E. for his great services to scholarship in Burma. Earlier on Daw Tee Tee had been awarded the Kaisar-i-Hind Gold Medal by the Government of India for her work on behalf of homeless children, and since on that occasion I thought he had expressed some objection to political honours, I asked him if he was willing to accept one himself. $\mathrm{He}$ replied, 'Yes, I am accepting it because this time it is for the very reason for which I was refused the Chair of English in the University of Rangoon in 1920.' Later he was to receive the degree of Doctor of Literature honoris causa from the University of Rangoon.

Much later after his final return from Burma he was the recipient in 1966 of the Triennial Gold Medal of the Royal Asiatic Society in London, and on this occasion he read to the Society his paper entitled "The career of Htilaing Min (Kyanzittha), the uniter of Burma, A.D. 1084-1113 '. This was published in the Society's journal, parts one and two of that year. Like his earlier paper - The early Syam in Burma's history', published in JBRS in 1958 and 1959, the Kyanzittha paper represented definitive advances in the study of Pagan's history, and a revision of the previously accepted views of two of its outstanding episodes, its rise to supremacy in Burma and its fall at the hands of Kublai Khan's Mongols. In 1939 in the article 'Burma down to the fall of Pagan' he had started to map out the main features in Burma's early history. This represented an uncompleted project since it went no further than the great dividing line between the period of Mon cultural ascendancy and that of Burmese cultural dominance which followed it in the latter part of the twelfth century. The importance of the Mons in the early history of Burma after the fall of the Pyu kingdom of Sri Kșetra in the eighth century attracted more and more of his attention as time went by and in 1953 in his JBRS article 'Mons of the Pagan dynasty ' he attempted a general survey of their history in both early Burma and early Thailand. These studies brought close contacts between himself and the scholars of Thailand, contacts which resulted in papers contributed to the Siam Society in Bangkok and published in 1965 in JSS. These were 'Dvaravati and Old Burma' and 'Rice and religion: a study of Old Mon-Khmer evolution and culture'. Both are of exceptional interest in the daring theories they contained. The most intriguing to me is his contention in the latter that the changeover to wet rice cultivation in Further Asia took place in the Red River Valley of Tongking and was the work of Mon-Khmerspeaking peoples. His Royal Asiatic Society lecture in 1966 returned to the theme of Mon cultural supremacy in early Pagan in greater detail.

These studies reached their culmination in his three-volume work Old Burma-Early Pagán (1969-70) which ends with the period of cultural changeover from Mon to Burman predominance. No study of the later Pagan period commensurate with this was to come; Gordon Luce would have had to add two more volumes to the work to cover the Burman period, but instead he turned his attention to the earlier history of the Burman people and in particular to the question of their origin in Central Asia, as he saw it. The results of this probe backwards in time appeared in two articles published shortly before his death, 'Kamram/Kamlam/Kamalanka' in JBRS, December 1976, and 'Tangut or Proto-Burman' in BSOAS, xLI, 3, 1978.

How far his daring theories regarding the origin and early wanderings of 
the Burman people, and his even more daring assertions regarding the discovery and spread of wet-rice cultivation by the Mon-Khmer-speaking peoples, will find ultimate acceptance by scholars, it is too early as yet to give a positive answer and beyond my own capacity. They constitute a splendid challenge. As I have suggested above, Gordon Luce's extensive linguistic studies were undertaken with a historical object. Languages were thus the key to historical discovery. In the process, however, linguistic studies often became an end in themselves, and it is difficult to say which interest predominated in his mind at any given time. Thus his researches in pursuit of the Proto-Burmans included a comparative study of early Burmese, Tibetan and Chinese. 'Rice and religion' in particular is an invaluable contribution to early South-East Asian historical discovery; it attempts to throw light upon a period of protohistory about which the ordinary historical materials hardly exist.

When Burma attained independence under $U$ Nu's premiership in January 1948 , one of the early acts of the new government had been to establish a historical commission to undertake research into existing materials for Burmese history and the discovery of more. Gordon Luce became an advisor to the Commission and he and his pupil, Bohmu Ba Shin, of the Burma Army Education Corps, busied themselves with the discovery of new materials for the history of early Burma. It was a fruitful partnership, particularly in the discovery of further inscriptions, and only ended with $\mathrm{Ba}$ Shin's early death. $\mathrm{Ba}$ Shin himself and Alexander Griswold jointly edited a presentation volume entitled Essays offered to $G$. $H$. Luce in honour of his seventy-fifth birthday (Ascona, 1966), to which a large number of valuable papers were contributed.

During these later years after the Japanese defeat, among Gordon Luce's special concerns was that of the continuation of the work of Blagden and Duroiselle on Burma's early inscriptions. He had performed the immense task of the restoration of the work he had lost through the destruction of the University of Rangoon library. His object was to produce a further volume of Epigraphia Birmanica which would complete its survey of all the known inscriptions of Burma up to the foundation of Ava in 1364-5. This work was uncompleted at his death. Writing to me in August 1978, he said, 'The next step is surely to edit properly the corpus of Old Burma's inscriptions which includes not only the 610 sheets of pre-Ava inscriptions clearly printed by the OUP, but also the even more numerous and more beautiful inscriptions of the Ava period that followed. There is no break in the continuity of these inscriptions from their very beginning in the eleventh century A.D.; and from the first their spelling is almost as archaic as Archaic Chinese, and their historical value beyond price. I doubt if any other country in South-East Asia can compare with Burma, either in number or continuity of stone inscriptions, though some beat us in antiquity. Blagden of SOAS and Duroiselle, a Frenchman, started the editing magnificently. What have we done, beyond the Oxford facsimiles? Pe Maung Tin and I edited in Burma the first twenty-five. Twelve, I think, were published : the rest were found last year in a cellar at Rangoon University, in final proof, utterly neglected by the Military Government.' During 1978 he recurred again and again to this matter in correspondence with me, urging that some institution should take over responsibility for this task and expressing the keenest desire that it should be undertaken by the School of Oriental and African Studies. He himself, and his pupil, U Tin Htway, had contributed an article on an Ava inscription of A.D. 1442 with translation and notes to the commemorative volume of essays presented to Dr. Malalasekera of Sri Lanka, and he recommended this as an example of the method to be used. 
Gordon Luce's views regarding the origin and early history of the Burmese people were revolutionary. They differed in every way from the accounts recorded in the Glass Palace Chronicle which were the dynastic myths of the Konbaung dynasty. These myths formed part of the teaching material of the monastic schools. They were cherished and defended by the Burmese nationalists in their struggles for independence against the British during the period anterior to the Japanese occupation. After Independence $\mathrm{U} \mathrm{Nu}$ himself perpetuated them in all his speeches and after the army takeover in 1962 the new regime tended to boost the traditionalism of the chronicles. But Luce's views were accepted by many educated Burmans, particularly those who had had personal contacts with him and realized that his interpretations were the result of studies of contemporary or near-contemporary evidence. It must also be mentioned that with the archaeological department of the Burma government Gordon Luce always had the utmost cooperation and friendly relations. In his preface to Old Burma-Early Pagán he offers his thanks for the 'priceless contribution' made by the department to that work. This is not to suggest that all his views found acceptance by Burmese archaeologists. But Gordon Luce's vast contributions to their knowledge of Pagan stimulated immense pride on the part of the educated classes in Burma in the true greatness of their past, as he saw it. This finds unforgettable expression in Win Pe's poem in The New Burma Weekly of 24 January 1959, entitled 'A temple of Pagan (A homage to Sayagyi Luce)', in which he praises 'his patience, piety and humbleness and his work which is a birth to us, for he has restored to us our inheritance against the wild conspiracy of time'. This was a special edition of this newspaper in commemoration of Gordon Luce's seventieth birthday. It contains a comprehensive collection of articles on practically every aspect of his work, together with a number of tributes, mainly by his Burmese past students. Their pride in his achievements and their deep affection for him personally are alike remarkable.

I). G. E. HALL

[Professor Hall had hoped to add a final paragraph dealing with Professor Gordon Luce's personal qualities, and did make the following notes; 'that he was essentially a poet: he wanted to die in Burma; he needed three lifetimes: as yet there is no one to fill his place. The beauty and wonder of Pagan, Burma's capital for two and a half centuries, demonstrated to him what the Burmese people were capable of at their best.'

Professor Hall died on 12 October 1979, before he could complete this essay. It has seemed best not to attempt to supply a conclusion, but to print this tribute to his lifelong friend as he left it. Eds.] 